\title{
News
}

\section{Soft ground technology conference planned for May 2000}

The US-based United Engineering Foundation and the ASCE Geo-Institute are planning a five-day conference on soft ground technology at Leeuwenhorst conference centre in Noorwikerhout, the Netherlands, from 28 May to 2 June 2000.

Technical sessions are planned on soft ground characterization, mechanical stabilization, chemical and thermal stabilization, tunnelling in soft ground and environmental aspects of soft ground. There will also be a programme of visits, including the GeoDelft Laboratory, a geosynthetics manufacturing plant and an environmental remediation site.

Conference fees, which include accommodation and meals, range from US\$ 1350 for a private room to US\$ 525 for a guest. Most delegates are expected to have backgrounds in geo- technical engineering, though the event is also likely to appeal to general civil, environmental and chemical engineers.

For further details contact United Engineering Foundation, Three Park Avenue, 27th Floor, New York, NY 10016-5902, telephone +1 212591 7836, fax +1 212591 7441, email engfnd@aol.com, web www.engfnd.org. 